
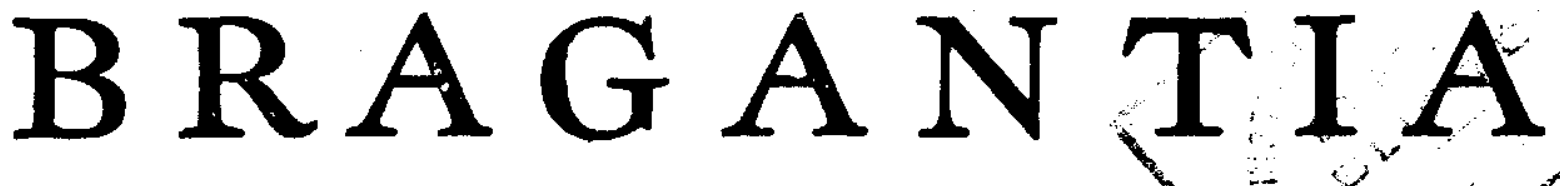

Boletim Técnico da Divisão de Experimentaça ou Pesquicyls IN STITUTO AGRONÔMICO

\title{
ALGUNS FUNGOS ENCONTRADOS EM S. PAULO, MINAS E ESPIRITO SANTO
}

A. P. Viégas

Reunimos neste trabalho umas poucas descrições de fungos mineiros, paulistas e também de um espírito-santense. Quase todos a que estas descrições se referem, foram coletados pelo professor E. P. Heringer, a quem externamos os nossos louvores pela paciência e habilidade $\mathrm{cm}$ coletar espécimes da flora micológica cabocla.

Cinco espécies, considerámo-las como novas, e como tal descrevemo-las. As demais são conhecidas. Cremos que Catacauma ingæ Chardon e Catacauma weirii Chardon, foram referidos agora, e pela primeira vez, para o nosso país. A coleta de Pterula pennata P. Henn., em Minas, ampliou consideràvelmente a área geográfica da clavariácea. Ustilaginoidea oryzæ Bref., tem suscitado interêsse por parte dos agrônomos regionais. Arremedando fungo produtor de carvão, o interessante parasita exótico parece que se vai adaptando às condições mesológicas brasileiras.

Gaillardiella caryocana n. sp. - Lesões nulas (Est. 1, a). Micélio superficial, formado de hifas cilíndricas, hialinas, de início septadas, que se reunem em camada tênue. $\bar{A}$ maturidade, fuscas, ocorrem à superfície da epiderme. São um bocado gelatinosas quando úmidas. Ao secar, adquirem a aparência de escamas de colódio, portadoras de pequenos lóculos negros (Est. 1, b) à superfície. Sob grande aumento, os lóculos se mostram como nas figuras $c$ e $d$ da estampa 1. Quando novos, os lóculos são pardacentos, globosos, de 50-60 $\mu$ de diâmetro ; à maturidade atingem $90-100 \mu$, e se abrem por um poro na parte distal. As hifas do micélio superficial se prendem à base dos lóculos. Esmagando-se um lóculo sob a lamínula, verifica-se que suas parcdes são um tanto espêssas, formadas por células poliédricas de 8-10 $\mu$ de diâmetro. No interior do lóculo se encontram ascos obclavulados, desprovidos de paráfises, de 40-50 x 8-10 $\mu$, curto-pedicelados, octosporos, parede espêssa e ápice bem espessado (Est. 1, e). Ascosporos (Est. 1, f) bicelulares, pardo-amarelo-escuros, constritos no septo, com a célula superior mais dilatada, e a basal um tanto cilíndrica ; medem os ascosporos 10-12 $\mathrm{x}$ 3-4,5u. 5385 - Sôbre fôlhas de Caryocar villosum Pers., leg. E. P. Heringer, 
Est. Exp. de Agua Limpa, Agua Limpa, Est. de Minas Gerais, 30 de abril de 1946. Nota : - Heringer $n .^{\circ} 398$, material colhido da planta $n .^{\circ} 1068$, da Est. Exp. de Água Limpa. Tipo.

Maculis nullis. Mycelio superficiale, ex hyphis cylindraceis, hyalinis, ab initio septatis, in strato tenuissimo dispositis, maturitate fuscis, humiditate gelatinosis, siccando squamas transparentes collophonio similibus efformantibus, loculos exhibentibus. Loculis coloratis, globosisque, $50-60 \mu$ diam., ad matsuritatem $90-100 \mu$, poro apicale pertusis, basi affixis, parictibus crassis ex-cellulis 8-10u diam. factis. Paraphysibus nullis. Ascis 40-50 × 8-10 $\mu$, brevi-pedicelatis, octosporis, perrietibus crassis, apice crassioribus. Ascosporis 10-12 x 3-4,5 $\mu$ bicellularibus, obseuro-fulvo coloratis, ad septum constrictis, cellula superiore majore, basale paulo cylindracea. In foliis vivis Caryocar villosum Pers., leg. E. P. Heringer, Lxt. Exp. Āgua Limpa, Ảgua Limpa, Minarum Provinciæ, Brasiliæ, Amer. Austr., April 30, 1946. Typus. Nota : - Heringer n. ${ }^{\circ} 398$.

Catacauma davilla $\mathrm{t}$. sp. -- Lesōes pròpriamente ditas, ausentes. Crostas (Fst. 2, a), negras, opacas, epífilas, isoladas, raro circundadas por um bordo côr de tijolo, elevadas, 1-2,5 $\mathrm{mm}$ de diâmetro, circulares, interessando apenas a parte superior do limbo, porquanto, na página inferior das fôlhas, os tecidos não exibem reação nenhuma. Sob a lupa de 14 diâmetros, as crostas se mostram lobulares, (Est. 2, b). A cada lobo corresponde um lóculo, que se abre à parte superior, por um poro bem nítido. Cortando-se uma crosta por plano perpendicular ao limbo (Lst. 2, e), se verifica que os lóculos são formados, na sua quase totalidade, no espaço entre a cpiderme estromatizada e transformada em clípeo e o tecido em paliçada (destruído em grande parte). Os lóculos são globosos, de 250-300 i̊ de diâmetro, deprimidos. Ocorrem em tôrno de uma área rentral, de baixo nível, estéril, do estroma onde estão imeros. As hifas formadoras do estroma se dispõem mais ou menos na vertical. São ramificadas, septadas, paredes onduladas, como que fimbriadas até (Fst. 2, d), 4-6u de diâmetro. Essas mesmas hifas se reunem formando uma como que parede locular, de 8-10 $\mu$ de espessura, bem visível nas porções basais dos lóculos. Na parte superior, nas adjacências do poro, a parede se confunde com o clípeo. O clípeo é formado de clementos hifais de 4-6 $\mu$ de diâmetro (Est. 2, d). Compacto, quebradiço, alcança $40 \mu$ de espessura na média. Ascos clavulados, 120-140 x 12-14u, octosporos, de paredes um tanto espêssas que se alargam inda mais no ápice, em tôrno do ascostoma (Est. 2, f). São providos de um pedicelo de 20-25:s. de comprimento, mais ou menos. Parafisóides numcrosas, septado-ramificadas de diâmetro variável, mais longas que os ascos. Ascosporos oblongoovóides, hialinos, gutulados (Est. 2 , g), 15-16 × 6-7 $\mu$, às vêzes um tanto constritos na porção mediana, às vêzes um tanto recurvos. 5384 - Sôbre fôlhas de Davilla rugosa Poir, leg. E. P. Heringer, Est. Exp. de Ȧgua Limpa, Est. de Minas Gerais, 30 de marȩo de 1946. Nota : - Heringer n. ${ }^{\circ} 391$. Tipo.

Maculis nullis. Crustis nigris, opacis, epiphyllis, isolatis, $1-2,5 \mathrm{~mm}$ diam., circularibus, salientibus, raro halu lateritia circumdatis, sub lupa lobulatis. Loculis globosis, immersis, 250-300 $\mu$ diam., depressis, juxte sub elypeo jacentibus et poro n'tido ac minuto apertis. Clypeis nigris, $40 \mu$ crass., ex-cellulis globosis, 4-6 $\mu$ diam., pariete nigra, undulata factis. Ascis clavulatis, $120-140 \times 12-14 \mu$, octosporis, parietibus incrassatis, pedicelo 20-25 $\mu$ longo præditis. Paraphysoidis numerosis, septatis, ramificatis, ascis superantibus. 
Ascosporis oblongo-ovoideis, hyalinis, guttulatis, 15-16 x 6-7 $\mu$, quandoque mediana parte constrictis quandoque paullulum recurvatis. In foliis vivis Davillæ rugosæ Poir, leg. E. P. Heringer, Est. Exp. de Água Limpa, Āgua Limpa (olim Coronel Pacheco), Minarum Provinciæ, Amer. Austr., Mars 30, 1946. Nota : - E. P. Heringer n. ${ }^{\circ} 391$. Typus.

Catacauma ingaE Chardon - Lesões quase não perceptíveis, circulares, diminutas. Estromas, na maioria hipofilos, negros, puntiformes, diminutos (Est. 3, a, b), de 500-800 $\mu$ de diâmetro, salientes, hemisféricos, negros, brilhantes, isolados, de 250-300 $\mu$ de altura. As hifas do fungo invadem os tecidos da epiderme, estromatizando-lhes as células; a seguir, são os elementos dos tecidos subjacentes atacados e desorganizados (Est. 3, c). As hifas do estroma, fuscas, dispõem-se mais ou menos na vertical. São septadas e alcançam 4-6 $\mu$ de diâmetro. Esta disposição das hifas é mais patente na área junto à inserção do estroma ; no tôpo formam emaranhado denso, fusco-negro, de 60-80 $\mu$ de espessura, clípeo, aberto no centro por um poro não muito evidente. Sob o clípeo pode ser constatada uma cavidade (ou duas) de 80-100 $\mu$ de altura, 150-170 $\mu$ de diâmetro. Quando há só um lóculo sob o clípeo, as dimensões são maiores : $300-400 \mu$. Os ascos são clavulado-cilíndricos, octosporos, curto pedicelados, 55-60 × $15-20 \mu$, providos de paredes espêssas, gelatinosas. Parafisóides não foram observadas por nós. Os ascosporos se dispõem em um ou dois grupos de quatro, na parte superior e inferior do asco ; são alongado-fusiformes, hialinos, de paredes delicadas, gutulados, retos ou recurvos, $24-35 \times 4-5 \mu$ (6), à maturidade levemente amarelados, e podem apresentar um pseudo-septo na porção quase que mediana (Est. 3, g). Como muito bem escreveu Chardon (3), a espécie com frequêneia passa despercebida em virtude da extrema pequenez dos estromas e carência de lesões típicas nos folíolos. 5395 - Sôbre folíolos de Inga sp., leg. E. P. Heringer, em material botânico colhido em Santa Leopoldina, Est. do Espírito Santo, em 30 de março de 1946. Nota : -Heringer $n .^{\circ} 390$. E a primeira constatação da espécie no Brasil.

Catacatima weirir Chardon - Estromas, quando novos (Est. 4, a) circulares ou irregulares, de 1-3 $\mathrm{mm}$ de diâmetro, planos, lisos, negros, epífilos. Correspondendo a êles, ocorrem, na página oposta, descoloraçð̄es pardacentas do limbo. Nas fôlhas mais idosas (Est. 4, b, c), são alongados ; acompanham as nervuras ; mais se parecem a túneis de lagartas. A côr, neste último estágio, é a de cera. Ao redor dos estromas, há um halo difuso, amarelo, visível à página superior. A cutícula, bem como a parte exterior da parede da epiderme, recobrem o estroma. Em corte transversal (Est. $4, d)$, o estroma alcança $200 \mu$ de altura, mais ou menos ; é negro, de textura intrincada, com a maioria das hifas correndo no sentido vertical; suas hifas são de côr escura, de $4 \mu$ de diâmetro e paredes um tanto espêssas ; invadem as células da epiderme, estromatizando-as em parte; ao depois é que se desenvolvem abaixo dela, dando origem a tôda massa estromática, onde, à maturidade, se formam lóculos. Os lóculos são globoso-deprimidos, numerosos, por vêzes coalescentes, de $160-180 \mu$ de altura, $100-400 \mu$ de diâmetro, sem poro nítido. Os ascos são clavulados com ápice truncado, octosporos, 150-180 x 10-12 $\mu$, com esporos unisseriados ; pedicelo 20-25 x 5-7 $\mu$. Parafisóides de 2-3 $\mu$ de diâmetro, gutuladas, mais longas que os ascos. Ascosporos elípticos, hialinos, lisos, de 12-16 × 5-7ị. 5489 - Sôbre fôlhas de 
Bauhinia sp.; (unha de vaca), leg. E.P. Heringer, Est. Exp. de Agua Limpa, Agua Limpa, Est. de Minas Gerais, 5 de julho de 1946. Nota : - - Heringer 11. ${ }^{\circ}$ 470. A espécie tipo provém da Bolívia (3).

Nummularia artocreas (Mass.) Mill. - Crostas (Est. 5, a) negras, circulares, de 5-10 $\mathrm{mm}$ de diâmetro na média, salientes, isoladas ou confluentes, ásperas na superfície (Est. 5, b), localizando-se sob o córtex. As hifas do fungo, pardo-avermelhadas, septadas, invadem os tecidos do córtex. Desenvolvendo-se activamente, esgarçam e separam os feixes fibrosos (Est. 5, c). A massa estromática ao atingir dois milímetros de espessura, mais ou menos, dá origem a peritécios, na parte mais exterior (Est. 5, b, c), cujos ostíolos, se localizam no tôpo de pequenas elevações cônicas, ou hemisféricas, negras, à maturidade abertos como pequenas crateras à superfície do estroma. A cada ostíolo corresponde um peritécio, imerso (Est. 5 , c), de forma de garrafa, longo, comprimido, de contornos um tanto gecmétricos, atro, de parede negra. Os peritécios medem $1 \mathrm{~mm}$ de altura, incluídos o bojo e o pescoço. Suas paredes carbonáceas, rijas, friáveis, se destacam no fundo pardo-vermelho do tecido estromático formado por células pseudoparenquimatosas de paredes espêssas de 10-20 $\mu$ de diâmetro. Nem ascos, nem paráfises foram observados, porque o material se achava um tanto passado. Os ascosporos (Est. 5, e), pardo-amarelados, oblongos, ou um tanto afilados para ambas as extremidades, plano-convexos, lisos, trazem fenda na face plana. Medem 13-15 x 6-8 $\mu$; à maturidade êles se reunem em massa compacta em forma de película delicada, parda, forrando a cavidade peritecial. 5369 - Sôbre galhos secos de planta indeterminada, leg. A. P. Viégas e outros, Faz. da Barra, Guedes, Est. S. Paulo, 10 de janeiro de 1946. Nota : - Devemos a identificação dêste material, ao Dr. Julian H. Miller, da Universidade de Geórgia, USA., a quem externamos os nossos agradecimentos.

Pterula pennata P. Henn. - Em agôsto de 1901, Ule coletou, sob n. ${ }^{\circ}$ 2711, em Juruá-Mirim, norte do Brasil, um fungo que, remetido a Hennings, foi identificado mais tarde como sendo Pterula pennata P. Henn. n. sp. (4), da família Clavariacex (5).

Desde então não se teve mais notícia da espécie. Passados quase 50 anos, ela surge novamente, agora em Minas Gerais.

Por se tratar de organismo muito bem caraterizado, procuramos, em nosso fichário, uma diagnose que se adaptasse ao material mineiro do qual havíamos feito os desenhos (Est. 6, a-f). Fomos felizes, porque logo de início demos com o nome que lembrava a espécie. A descrição henningsiana, incompleta, traz indicações precisas acêrca dos basidiosporos. $E$ bem provável que Hennings ao examinar os espécimes colhidos à margem do Juruá, não houvesse encontrado basídias portadoras de esterígmas, aliás, difíceis de serem observadas. Apenas em dois casos pudemos verificar basidiosporos novos inda presos aos esterigmas (Est. 6, d, e). Corroborando essas nossas observações, pudemos constatar ainda que os basidiosporos são bíjugos, isto é, aparecem aos pares, quando novos. 
Os espécimes mineiros, quase brancos, alcançam 1,5-2 centímetros de altura. Compõem-se de uma haste frágil, cilíndrica (Est. 6, a, b), de 300$400 \mu$ de diâmetro, de aspecto pulverulento, da qual partem ramos laterais, incurvos, de menor diâmetro, afilados, de comprimento vário, (na maioriạ 0,5-3 $\mathrm{mm}$ ), férteis em tôda a circunferência. A base da haste principal é recoberta de hifas ou feixes de hifas que emprestam aparência sub-vilosa à superfície (Est. 6, c). Examinando-se um ramo ou um fragmento da haste principal sob o microscópio, verifica-se ser revestido por estrutüras clavuladas, ávidas de corantes, gutuladas, numerosas, junto à inserção do ramo, em menor número para a extremidade, onde os ramos não vão além de mero feixe de hifas paralelas. As basídias (Est. 6, d, e) maduras são portadoras (raro) de 2 esterigmas delicados e um tanto curvos. Clavuladas, exibem grandes gotas de substância oleosa; medem 20-40 x 10-12 $\mu$. Os basidiosporos (Est. 6, f) hialinos, lisos, piriformes ou ovóides, trazem na parte basal um apículo bastante nítido. A parede dos basidiosporos é espêssa à maturidade. O protoplasma do esporo é grosseiro e portador de uma ou mais gotas de substância refringente. Medem os basidiosporos 10-13 x 7-8 $\mu$. O apículo alcança mais ou menos $1-2 \mu$ de altura. 5458 - Sôbre madeira apodrecida na mata, leg. E. P. Heringer, Est. Exp. de Ågua Limpa, Ãgua Limpa, Est. de Minas Gerais, 28 de maio de 1946. Nota : - Heringer n. ${ }^{\circ} 429$.

Gloeosporium sp. - Em data de 25 de novembro de 1945, coletamos, sôbre frutos de ponhemeria (Myrciaria sp.), um fungo que, sob exame de laboratório, revelou ser um Gloeosporium.

$O$ fungo ataca especialmente os frutos picados por mosca. As hifas do parasita invadem, rápidas, os tecidos, encarquilhando-os, mumificando-os completamente (Est. 7, a).

O local ao derredor da infeção se torna levemente colorido de vermelho. Dentro em breve os tecidos vão perdendo água, e, no fim, tôda a superfície se apresenta como que talhada, em superfícies as mais díspares. A côr do fruto, de brilhante passa a opaca e por último se torna negra.

Sob a lupa de 14 diâmetros, a superfície do fruto recem-atacado, mostra numerosos cirros de esporos (Est. 7, b). São longos, róseos ou amarelos, ou esbranquiçados, sinuosos ou enrolados em caracol, alcançando quase milímetro de comprimento e cêrea de $40-50 \mu$ de diâmetro. Os acérvulos do fungo, quando vistos de cima, se apresentam como pequenas ampolas subepidérmicas (Est. 7, b, c). $\bar{A}$ maturidade, a epiderme recobrindo os acérvulos se abre irregularmente no tôpo, pela pressão da massa de esporos. Os conidióforos, hialinos, de $10-20 \mu$ de altura e cêrca de $2,5 \mu$ de diâmetro, provindo dum plexo basal, se dispõem em forma de paliçada de sob a epiderme parcialmente desfeita. As células poligonais, da epiderme (Est. 7, c), são invadidas por haustórios recurvos, ou são penetradas diretamente pelas hifas. $\bar{A}$ extremidade dos conidióforos se formam esporos muito irregulares na forma e tamanho; variam desde 6 até $20 \mu$ de comprimento e de 2,5 a $4 \mu$ de diâmetro. São às vêzes piriformes, retos ou recurvos. O tipo mais frequente é o reto, alongado-elíptico. 5077 - Sôbre frutos de Myrciaria sp., (ponhemeira), leg. A. P. Viégas, rua do Rosário, Piracicaba, Est: de S. Paulo, 25 de novembro de 1945. 
Melanconium nectandræe $n$. sp. - Lesões anfígenas, circulares ou irregulares, pardo-avermelhadas, bordejadas de negro (Est. 8, a) com pontuações pretas à página inferior, lisas, zonadas à pagina superior, esparsas ou confluentes, variando de $2-3 \mathrm{~mm}$ a vários centímetros de diâmetro. Quando as pontilhações negras são examinadas à lupa de 14 diâmetros, (Est. 8, b), vê-se que são acérvulos, semelhantes a pequenas bolhas negras que tivessem sido rebentadas, e das quais corresse um líquido ceroso, colorido-massa de esporos. Em cortes transversais, as pontuações negras exibem espécie de subículo estreito, levemente colorido, basal, do qual partem conidióforos na direção vertical. Em pequeno aumento, os conidióforos parecem ser simples. Examinados sob imersão, verifica-se que são ramificados, septados, de $15-20 \mu$ de altura e 2-3 $\mu$ de diâmetro. Os ramos laterais, bem como o ramo terminal são afilados para a extremidade, a qual subtende, no mais das vêzes, uma conídia. O ponto de partida dum ramo lateral do conidióforo é sempre abaixo do septo (Lst. 8, d). As conídias, (Est. 8, c), numerosíssimas, são hialinas quando isoladas. Em massa, apresentam a côr pardo-fusca. São lisas, oblongo-alongadas, com a parte distal arredondada, e a basal afilada em tronco de cone. Medem 6-10 x 2-3 $\mu$. 5487 -Sôbre fôlhas de Nectandra sp., (canelão), leg. E. P. Heringer, Est. Exp. de Āgua Limpa, Agua Limpa, Est. de Minas Gerais, 23 de junho de 1946. Nota : -.- Heringer n. ${ }^{\circ} 462$. Tipo. Como se verifica pela descrição acima, os esporos, por serem muito pequenos, parecem hialinos. A massa dêless é pardo-fusca. Os conidióforos, são ramificados. Nesse particular, a espécie se afasta dos caracteres genéricos. Mas ccmo o fungo deve ser o estado perfeito dalgum ascomiceto, não importa deixá-lo como acima, até que melhores pesquisas venham colocá-lo no devido lugar na classificação. Evidentemente, os caracteres do organismo não se enquadram em os de Pscudomelasmia lauracearum P. Henn. (7).

Maculis amphigenis sparsis aut confluentibus, circularibus vel irregularibus, lateritiis, margine nigra cinctis, inferne-nigro-punctulatis, glabrisque zonatis ad superiorem paginam, $2-3 \mathrm{~mm}$ vel plus quam $\mathbf{c m}$ latioribus. Acervulis nigris subiculum angustum paulo coloratum donatis. Conidiophoris ramificatis, septatis, $15-20 \times 2-3 \mu$. Conidiis numerosissimis, hyalinis quando isolatis, (agglutinando roloratis) oblongo-elongatis, lævibus, $6-10 \times 2-3 \mu$. In foliis vivis Nectandræ sp., leg. E. P. Heringer, Lst. Kxp. Água Limpa, Āgua Limpa, Minarum Provinciæ, 13rasiliæ, Amer. Austr., Jul. 23, 1946. Typus. Nota : - Heringer $n .^{\circ} 462$.

Ustilaninoidea ortzae Bref. --.- Das mãos do Sr. Túlio Ribeiro Rocha recebemos, em data de 22 de abril de 1946, uma carta acompanhada de panículas de arroz atacadas por um fungo. O organismo afetava as espiguetas (Fst. 9, a), deixando intartas as glumas (Est. 9, b) ; crescia bastante, formando verdadeiras bolas de côr azeitona ou fulva. $O$ diâmetro das bolas era um pouco maior que o grão atacado. Quando uma bola foi cortada (Est. $9, \mathrm{~b})$, verificamos que a parte mais exterior negro-fulva, pulverulenta, era seguida, logo abaixo, por outra mais larga, firme, branca, a qual, em contacto com os tecidos da gramínea, adquiria tonalidade avermelhada. Os esporos do fungo, (Est. 9, ( ), cram globosos on oblongos, fuligíneos, equinulados esparsamente, de paredes nẫo muito cspêssas, protoplasma granufoso. Mediam 5-8; de comprimento a 4,5-5,5is de largura. 
Quando esporos foram semeados em agar de batatinha, germinaram, dando origem a um tubo de $2 \mu$ de diâmetro, hialino, que se ramificava logo. Nas extremidades dos ramos se produziam esporos que tendiam a se reunir em bolas (Est. 9, d). Êsses esporos eram quase que das mesmas dimensões que os encontrados nos grãos atacados. Eram lisos, hialinos, de paredes bem mais claras. Nasciam distal ou pleurogenamente, nos ramos hifais (Est. 9, e).

O fungo crescia com vagar, nos tubos de cultura. Formava colônias salientes, de côr fulva. As hifas, de início hialinas e de $2 \mu$, adquiriram coloração esverdinhada (em líquido de Amann), alcançando $4 \hat{\mu}$ de diâmetro. Emaranhavam-se ao mesmo tempo que se tornavam septadas, dando origem após 20 dias a um estroma mais ou menos semelhante ao constatado nos grãos de arroz in natura, bem como os esporos amarelo-esverdinhados, ásperos.

Depois de havermos examinado o organismo a partir de material recentemente colhido e proveniente das culturas artificiais, concordamos em designá-lo pelo nome que lhe dera Brefeld (2). De acôrdn com êsse autor (2), o fungo ocorre no Japão, Î́ndia.

E a primeira constatação dêle aqui em S. Paulo, ou, quem sabe mesmo, no Brasil. A questão da posição taxonômica de Ustilaginoidea oryzæx, foi discutida por Brefeld. Hoje, parece estar bem aceito que o fungo pertence ao grupo dos Fungi imperfecti (1). A ação bacteriostática do hifomicéso foi constatada pelo autor alemão.

Parece que o fungo nos veio do Japão. Acêrca da importância econômica à cultura do arroz sob nossas condições, nada podemos afirmar por hora. A observação de Brefeld (2) que confirmamos, é que, numa panícula, a maioria dos grãos é sadia. $\mathbf{5 3 6 7}$ - Sôbre panículas de Oryza sativa L., (arroz), leg. Túlio Ribeiro Rocha, Franca, Est. de S. Paulo, 22 de abril de 1946. 7239 - Uma segunda coleta feita pelo Sr. Ernesto Barbanti, em arrozal de Orlândia, neste Estado, e recebida em 14 de abril de 1947.

Cercospora stylogynis ‥ sp. - Lesōes (Est. 10, a) anfígenas, esparsas, irregulares, pardas, variando de 1 milímetro até 1 centímetro de diâmetro, circundadas por um halo amarelo. As margens das áreas necroticas são de coloração mais carregada. O centro é de côr mais clara. Esporodóquios anfígenos, numerosos, pardo-negros quando velhos, acinzentados quando novos, salientes. Bulbilhos (Est. 10, b, c) globosos, de côr parda, um tanto salientes, 20-120 « de diâmetro. Conidióforós (Est. 10, b, c) em feixes, cilíndricos, septados, 1-geniculados, com ápice abrupto-truncado, pardo-fuscos. Quando observados em esporodóquios antigos, os conidióforos medem apenas 40-60 $\mu$ de comprimento e de 5-6 $\mu$ de diâmetro. Quando fôlhas são colocadas em câmara úmida se nota que podem alcançar $200 \mu$ de comprimento, 5-6 $\mu$ de diâmetro. Conídias aciculadas, base obtroncônica, hialinas, septadas, flexuosas, quando novas vacuoladas, ápice agudo 120-200 x 4-4,5 4565 - Sôbre fôlhas de Stylogyne ambigua (Mart.) Mez., leg. A. P. Viégas, Bosque dos Jequitibás, Campinas, Est. S. Paulo, 2 de julho de 1944. Tipo. 4574 - Sôbre fôlhas de Stylogyne ambigua (Mart.) Mez., leg. C. G. Teixeira, 
Bosque dos Jequitibás, Campinas, Est. S. Paulo, 10 de julho de 1944 . 5516 - Sôbre fôlhas de Stylogyne ambigua (Mart.) Mez., leg. A. P. Viégas, C. G. Teixeira e D. M. Dedecca, Bosque dos Jequitibás, Campinas, Est. S. Paulo, 25 de setembro de 1946. Nota : - Durante os meses de julho-setembro, as árvores atacadas exibem um aspecto todo especial, em virtude das grandes lesões nas fôlhas grandes da mirsinácea. 7331 - Sôbre fôlhas de Stylogyne ambigua (Mart.) Mez., leg. A. R. Teixcira e M. J. Nowacki, Bosque dos Jequitibás, Campinas, Est. S. Paulo, 12 de setembro de 1947.

Maculis amphigenis, sparsis, 1-10 mm. diam., fuscolateritiis, paulo depressis, centro albescentibus, irregularibus. Sporodochia amphigena, numerosa, senescendo fusconigra, juventute, cinerascentia. Bulbilis globosis, fuscis, salientibus, 20-120 $\mu$ diam. Conidiophoris fasciculatis, cylindraceis, 40-200 x 5-6u, fuscis, apice abrupte truncatis, paucis septis donatis. Conidiis hyalinis, septatis, flexuosis, acicularibus, apice acutis, 120-200 $x$ 4-4,5 $\mu$. In foliis vivis Styloginis ambigua (Mart.) Mez., leg. A. P. Viégas, Bosque dos Jequitibás, Campinas, Prov. St. Pauli, Brasiliæ, Amer. Austr., jul. 2, 1944. Typus.

\section{LITERATURA CITADA}

1. Ainsworth, G. C. e G. R. Bisby. Em A dictionary of the fungi, pgs. 1-431, fig. 1-138. $2{ }^{\Omega}$ ed., 1945.

2. Brefeld, Oscar. Untersuchungen aus dim Gesammtgebiete der Mykologie 11 : 194-202. 1895.

3. Chardon, C. E. New or interesting tropical American Dothideales -- II. The Jour. of the Dept. of Agriculture of Porto Rico 13 : 5-17. est. 1-2. 1929.

4. Hennings, P. Fungi amazonici I. a cl. E. Cle collecti. Hedwigia 43 : 154-186. 1904.

5. Killermann, S. Clavariaceæ. Em Engler \& Prantl, Die natuerlichen Pflanzenfamilien $6: 151-158,2 .^{2}$ ed., W. Engelmamn, Leipzig, 1928.

6. Orejuela, C. G. New or heretofore unreported species of higher Ascomycetes, from Colombia and Venezuela. Mycologia $36: 429-459.1944$.

7. Theissen, F. e II. Sydow. Die Dothideales. Annales Mycologici 13 : 149-746. est. 1-6. 1915. 
Est. 1
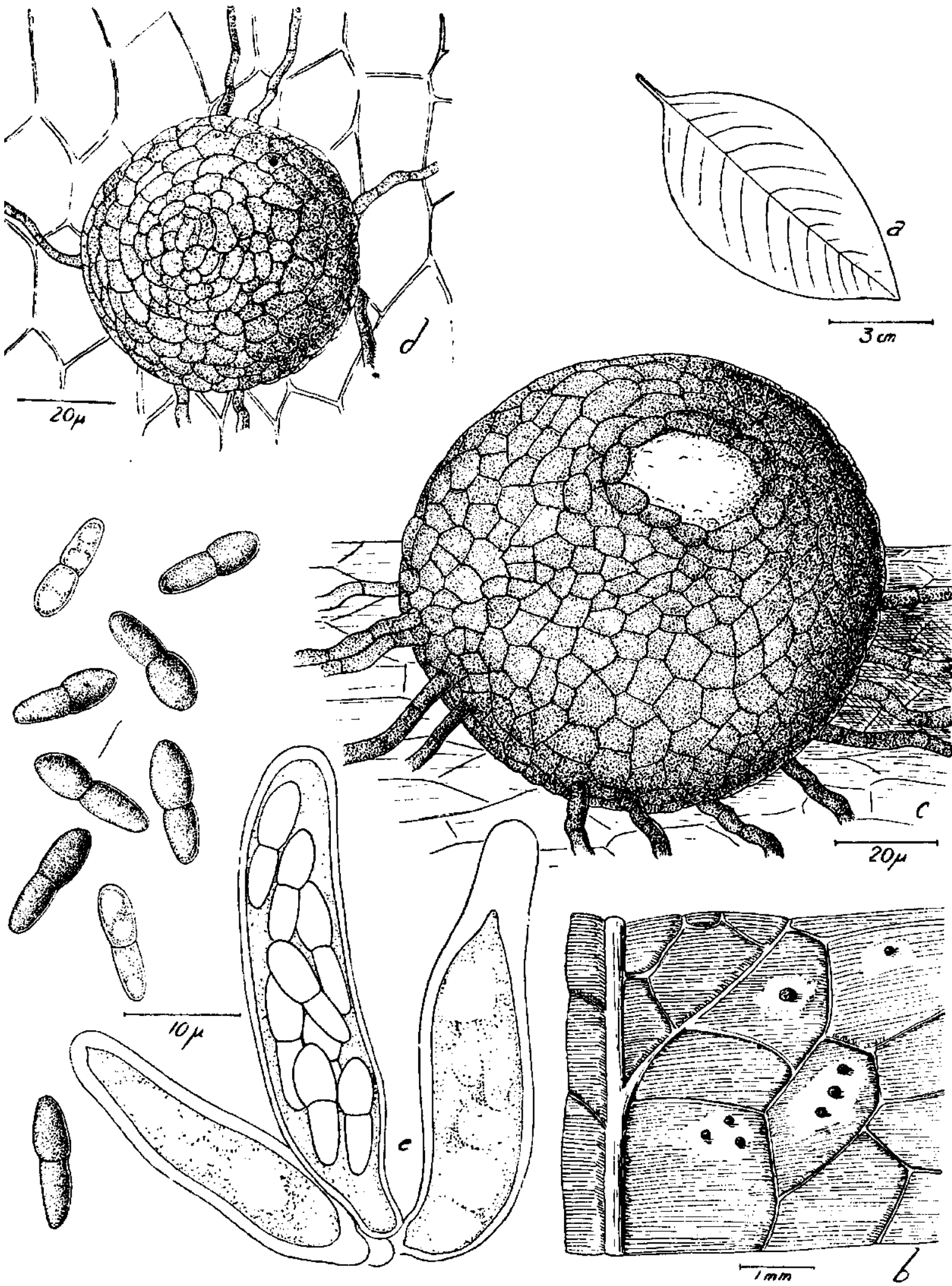

Gaillardiella caryocana n. sp. 
Est. 2
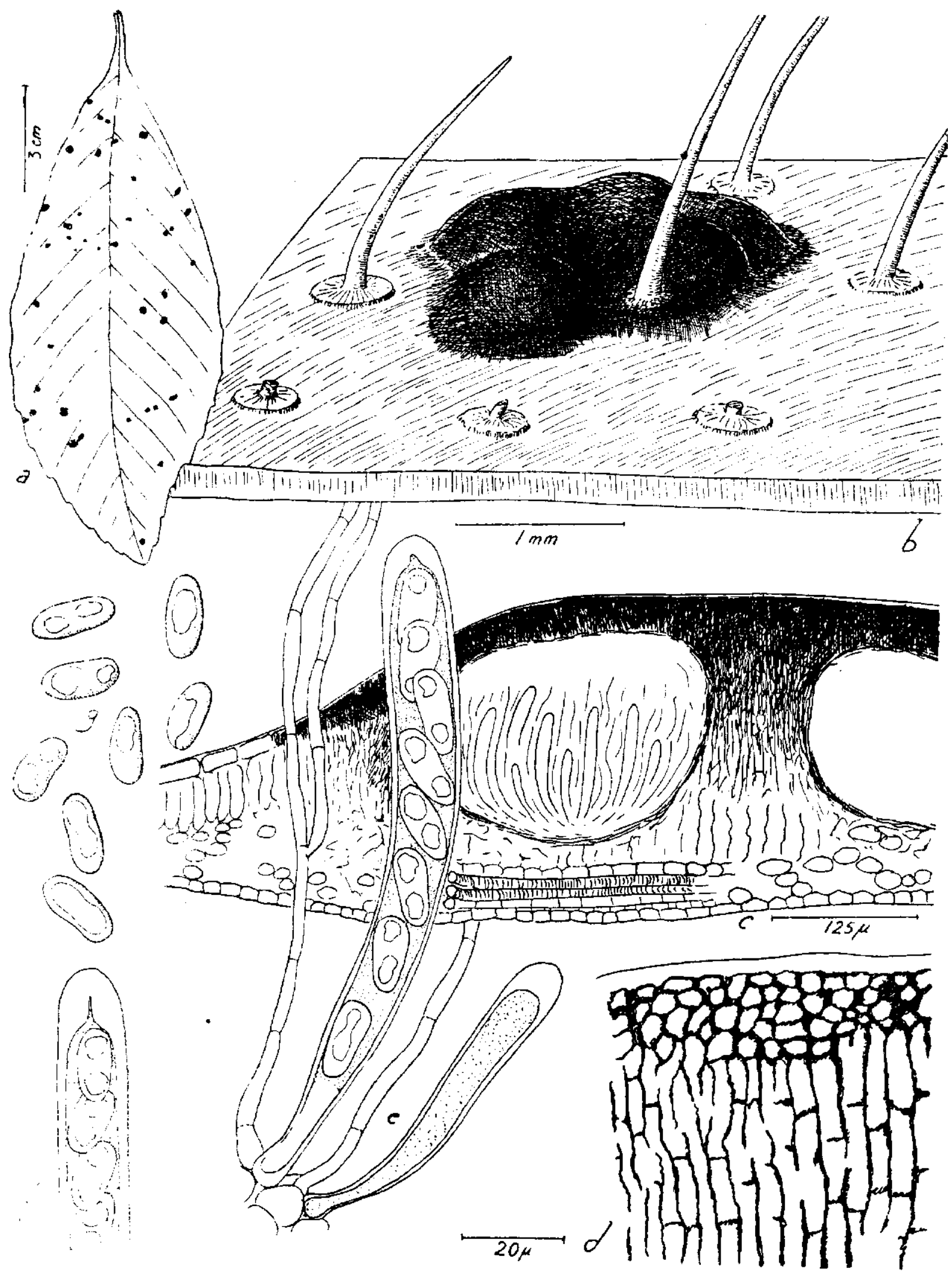

Catacauma davillae n. sp. 
Est. 3
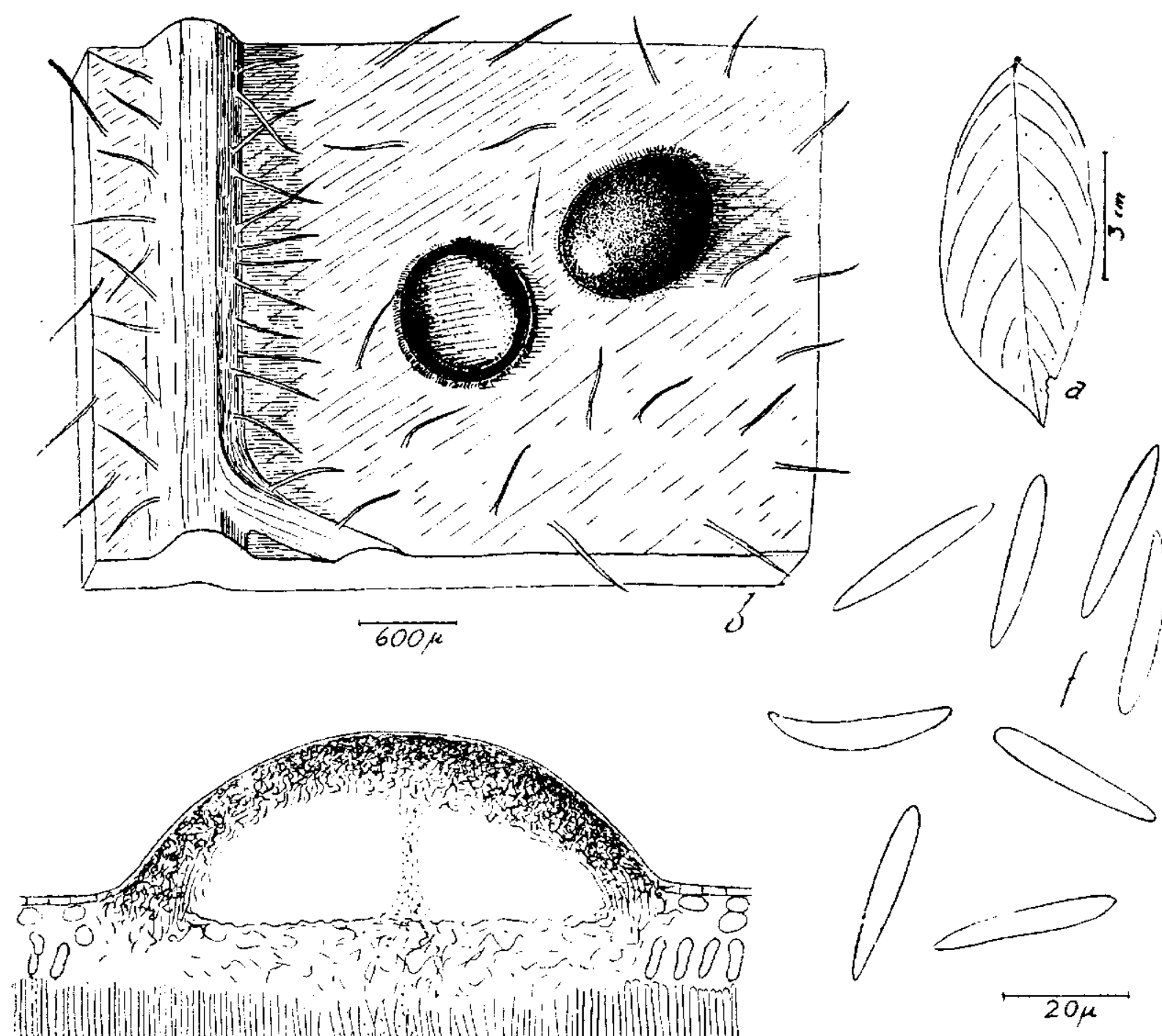

(1)

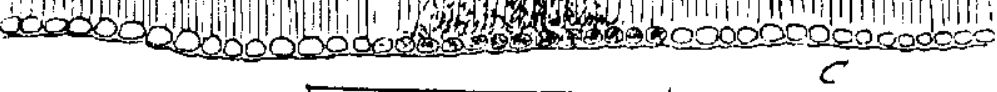

$$
500 \mu
$$
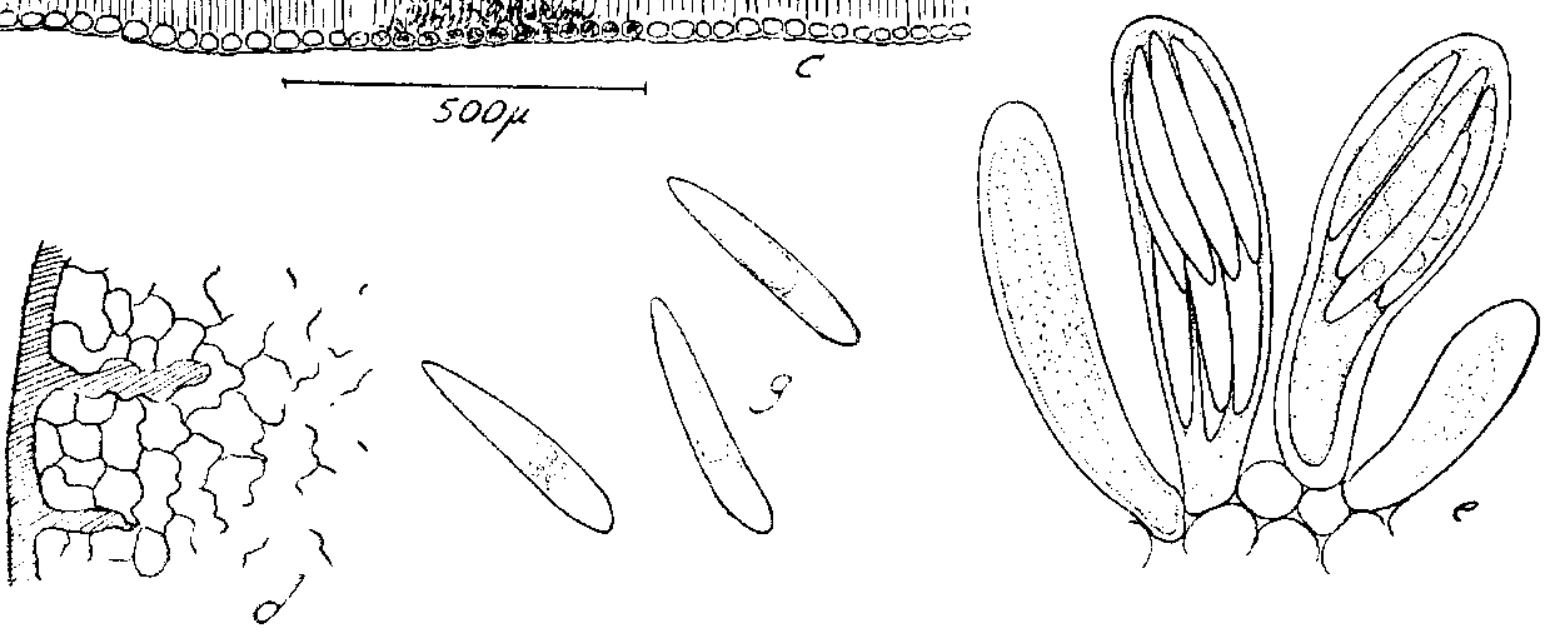

Catacauma ingae Chardon 

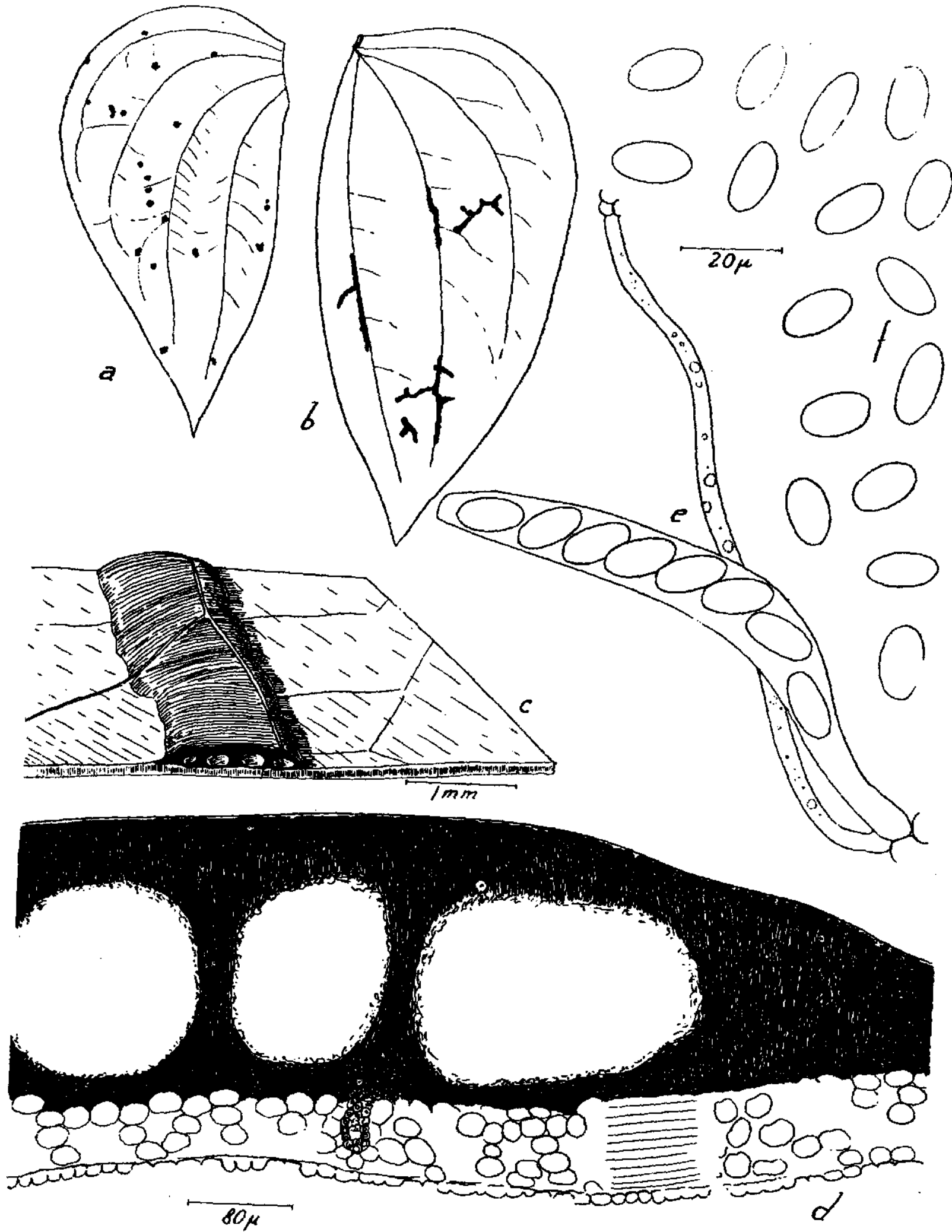

Catacauma weirii Chardon 
Est. 5
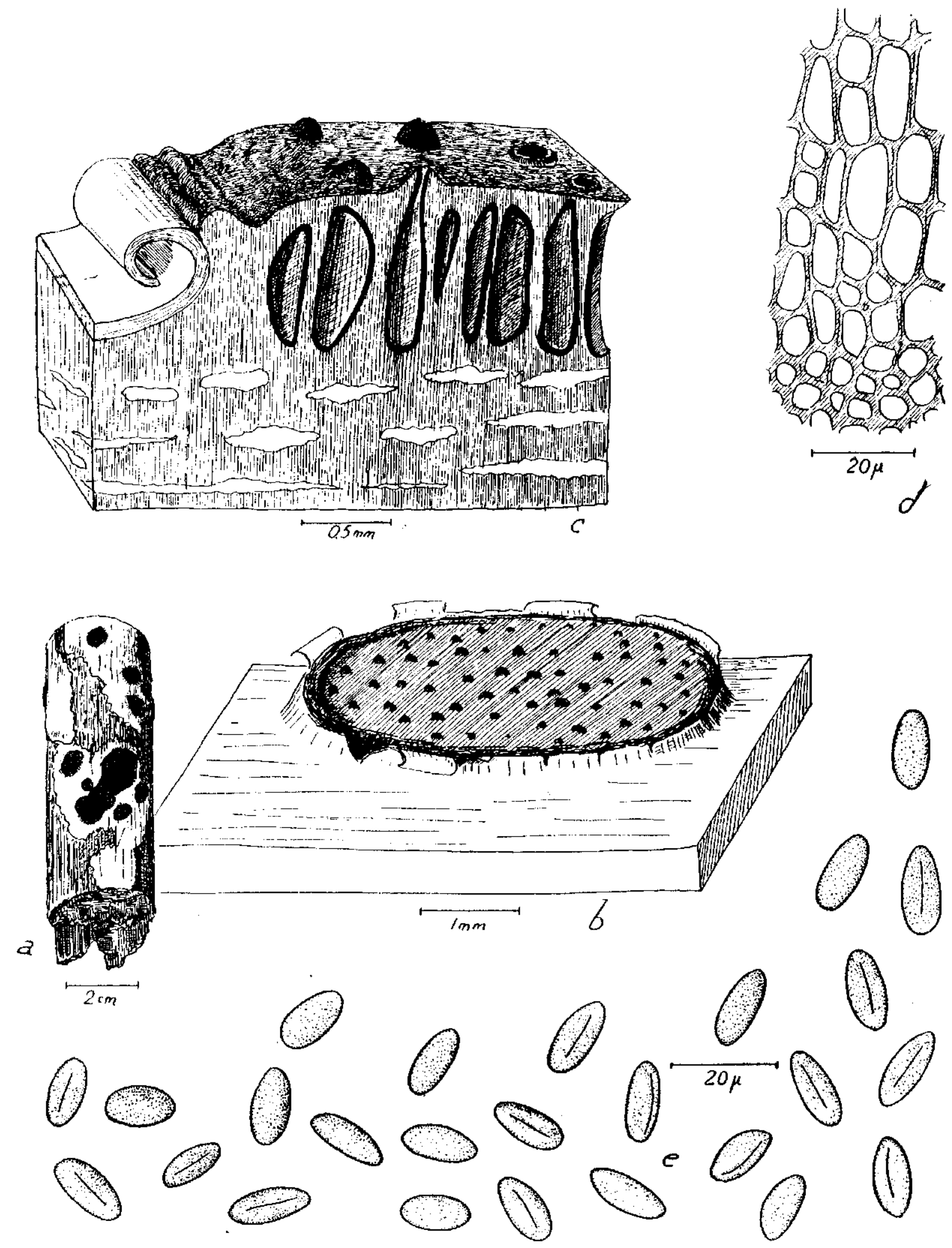

Nummularia artocreas (Mass.) Mill. 
Est. 6

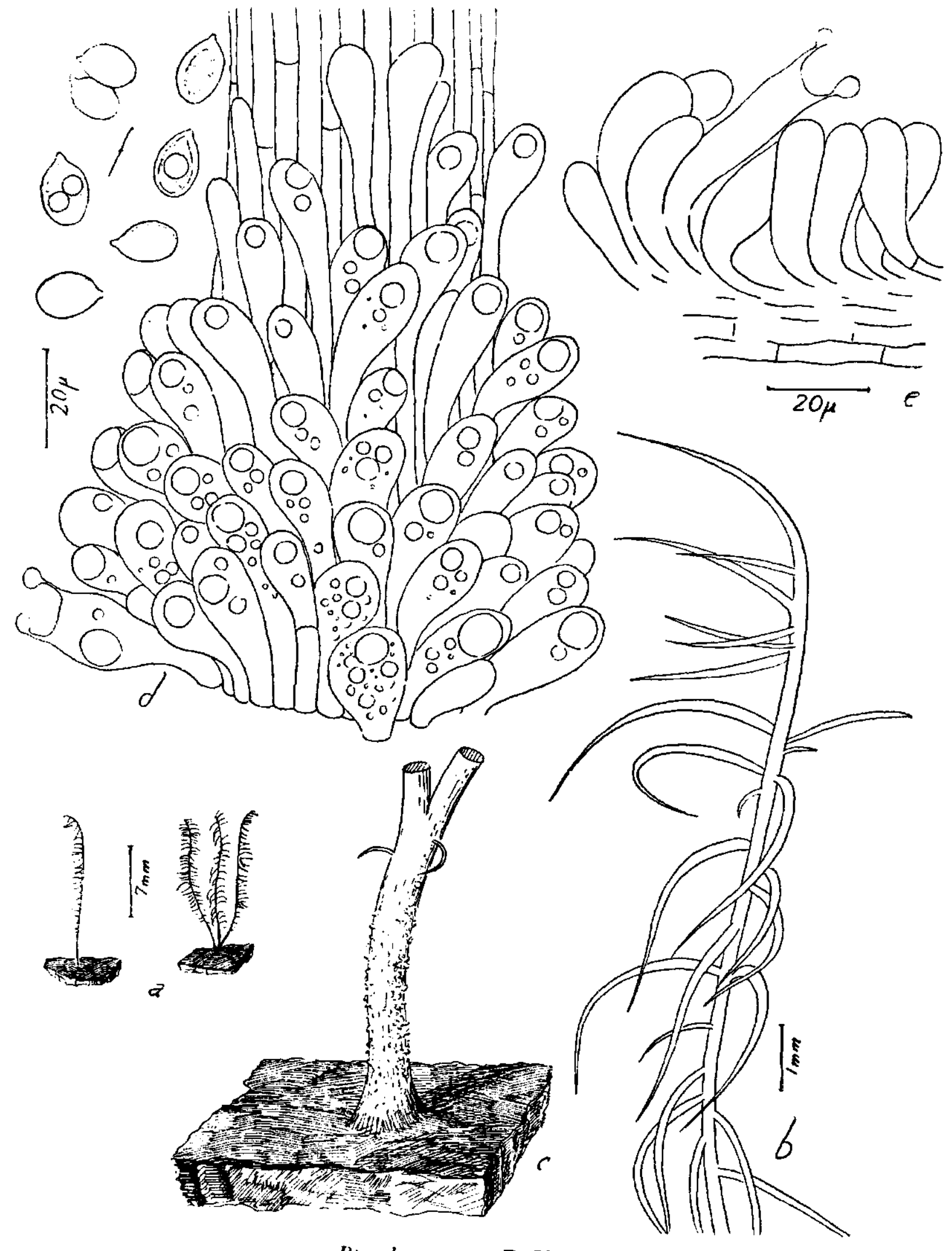

Pterula pennata $\mathrm{P}$. Henn. 
Est. 7

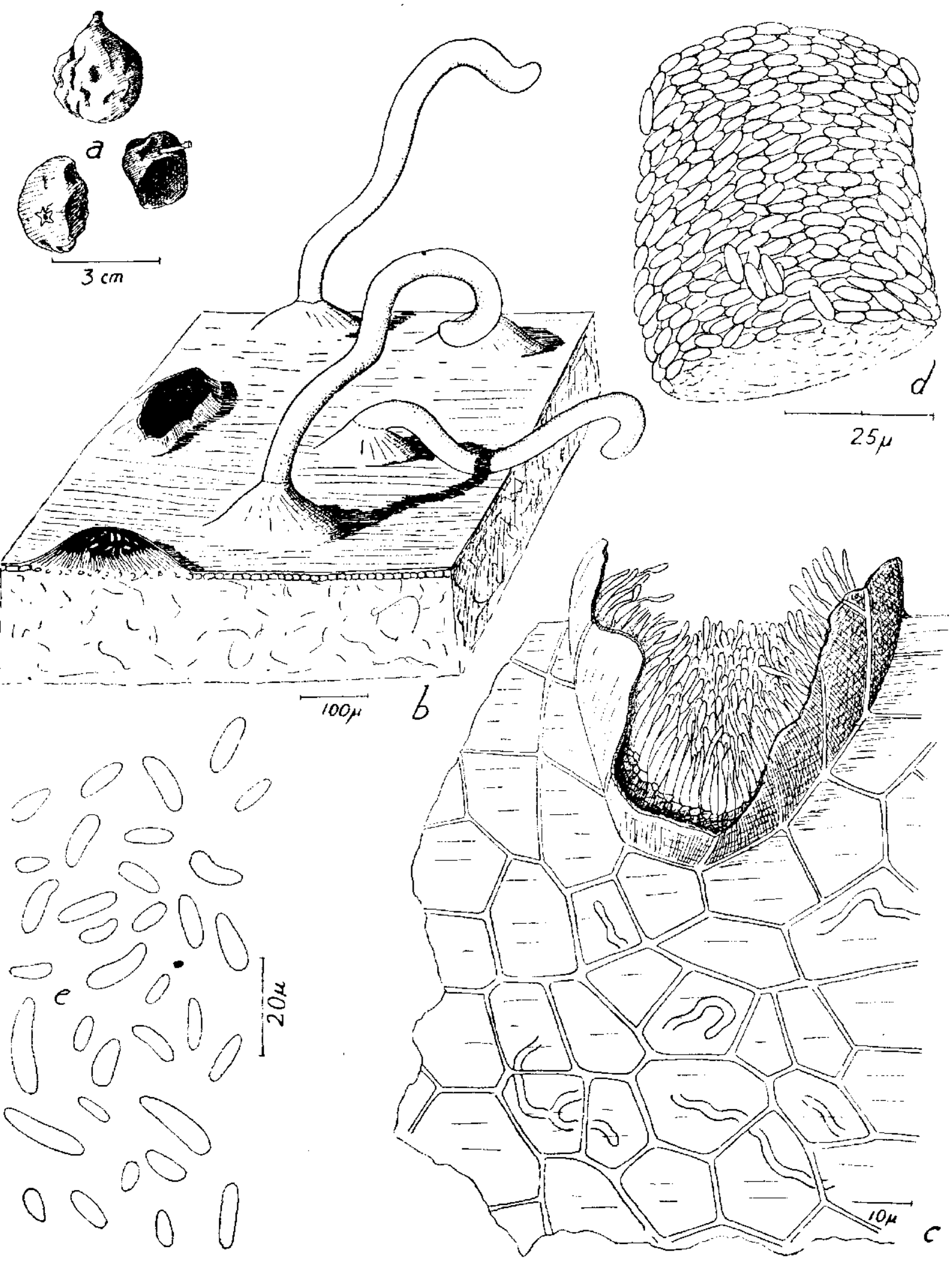

Gloeosporium sp. 
Est. 8

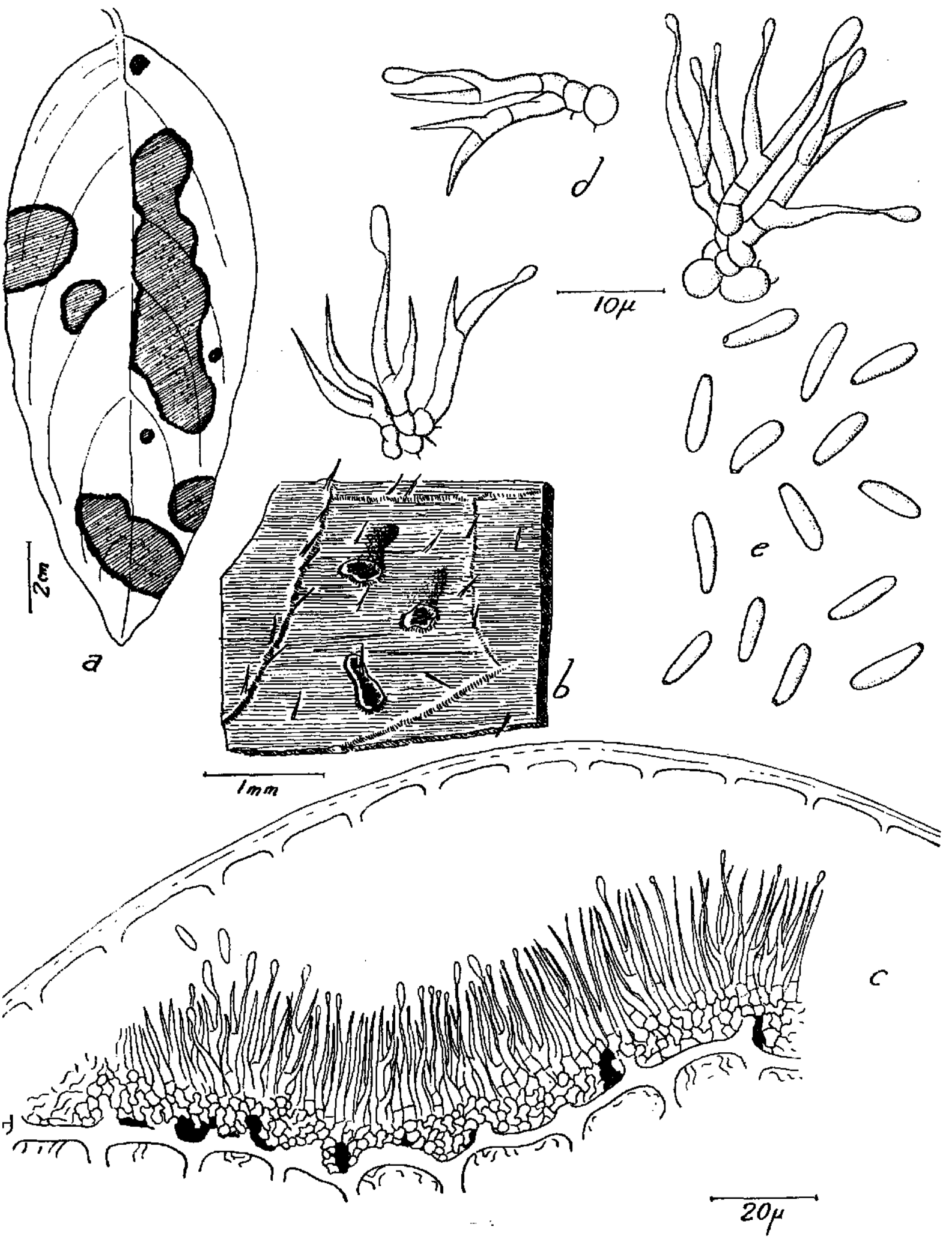

Melanconium nectandrae n. sp. 

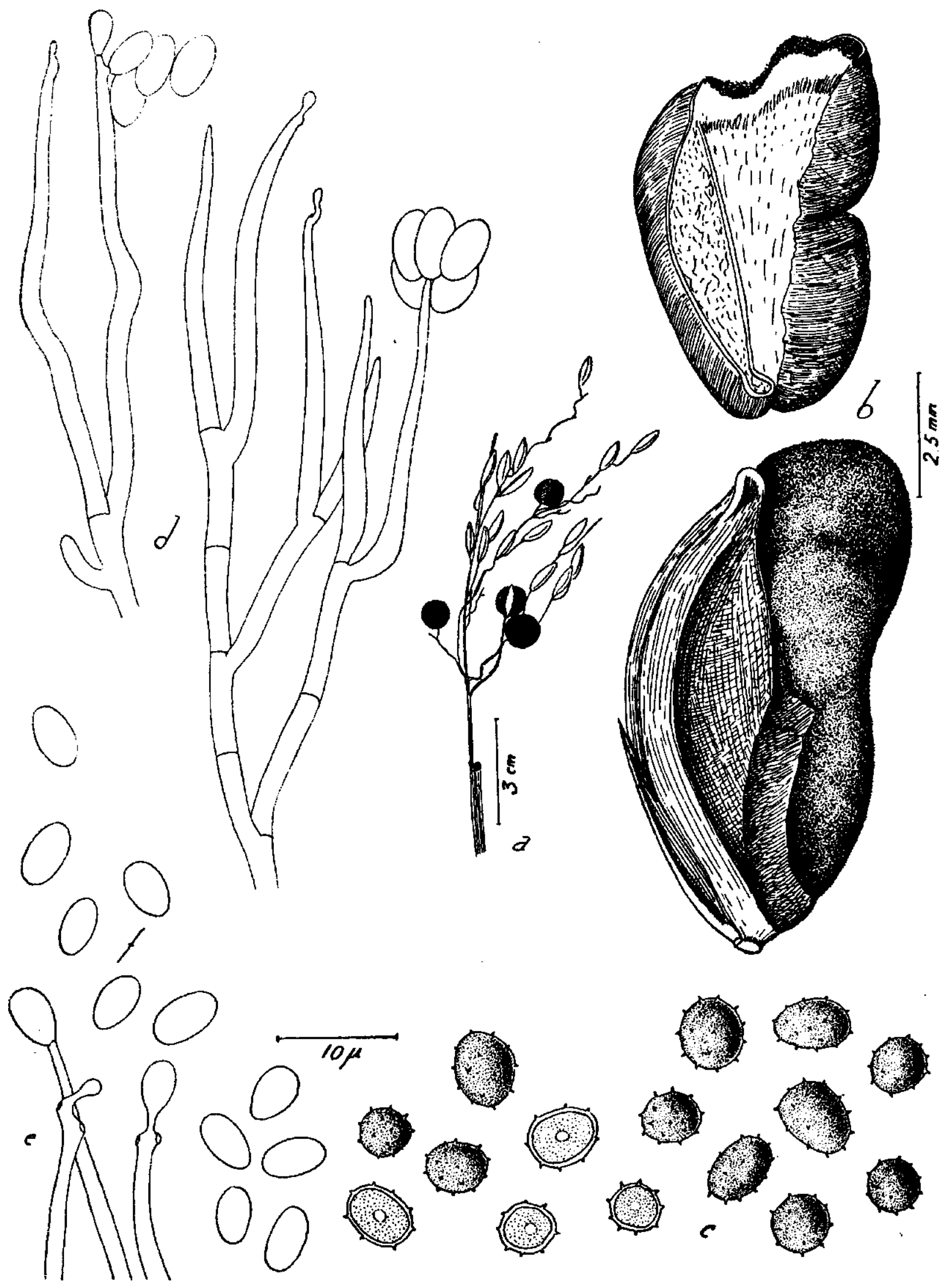

Ustilaginoidea oryzae Bref. 


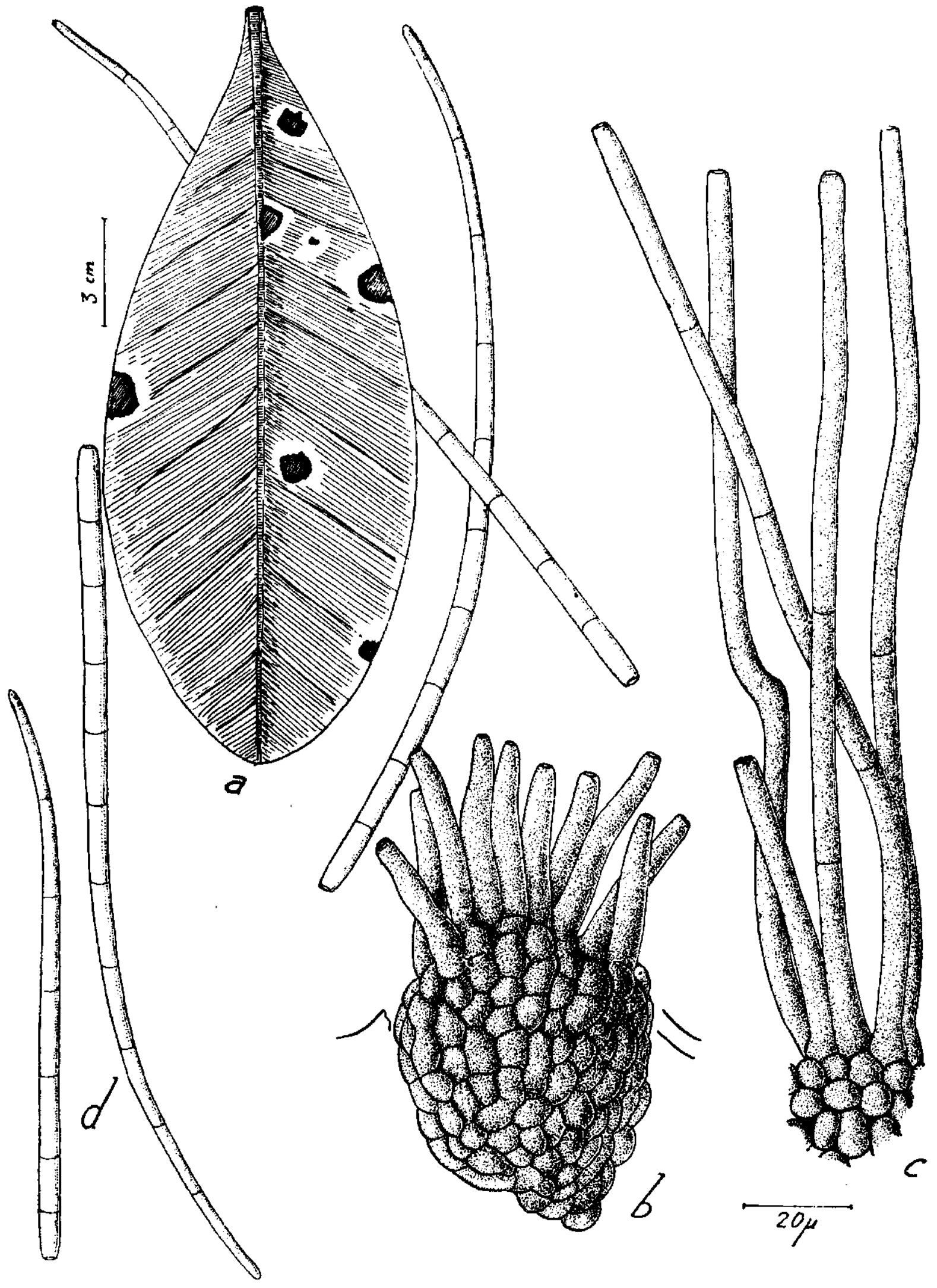

Cercospora stylogynis n. sp. 